\title{
Correspondence
}

\section{研究室紹介 \\ 福岡大学 工学部 化学システム工学科 \\ 工業化学・高分子研究室}

\author{
八尾 滋*
}

(原稿受理：2019 年 1 月 21 日)

\section{1. はじめに（大学・学部・学科紹介）}

福岡大学の前身である福岡高等商業学校は 1934 年に設立 されており，本年（2019年）は設立 85 周年にあたる. 1935 年から現在の所在地である七隈にキャンパスを構えている (Fig. 1 には 80 周年に新設された中央図書館を示す). 1944 年には福岡高等商業学校と九州専門学校（(財) 弘文学舎設 置）を統合し, 九州経済専門学校となり，1946 年に福岡経 済専門学校と改称, 1949 年には福岡経済専門学校と福岡外 事専門学校 ((財) 福岡外国語学園設置) を統合し, 福岡商 科大学が設立された。 1956 年に福岡大学と改称され, 現在 は人文学部, 法学部, 経済学部, 商学部, 商学部第二部, 理 学部, 工学部, 医学部, 薬学部, スポーツ科学部の全 10 学部, 学生数約 2 万名の総合大学となっている. 建学の精神は, 「思 想堅実」「穏健中正」「質実剛健」「積極進取」の 4 つである.

工学部は 1962 年に機械工学科と電気工学科が設立された のが最初であり, 筆者が所属している化学システム工学科は 1969 年に化学工学科として設立されている（その後, 2003 年に化学システム工学科に改称).したがって 2019 年は設立 50 周年にあたり，これまでの卒業生も 4,000 人を超えている. 化学システム工学科は全 10 教室から成り立っており, 伝統 的な化学工学系のプロセス研究を行っている研究室から, 有 機系・無機系の最新の機能性材料を研究開発している研究室 もあり, 網羅している研究範囲は非常に幅広い. 2018 年か

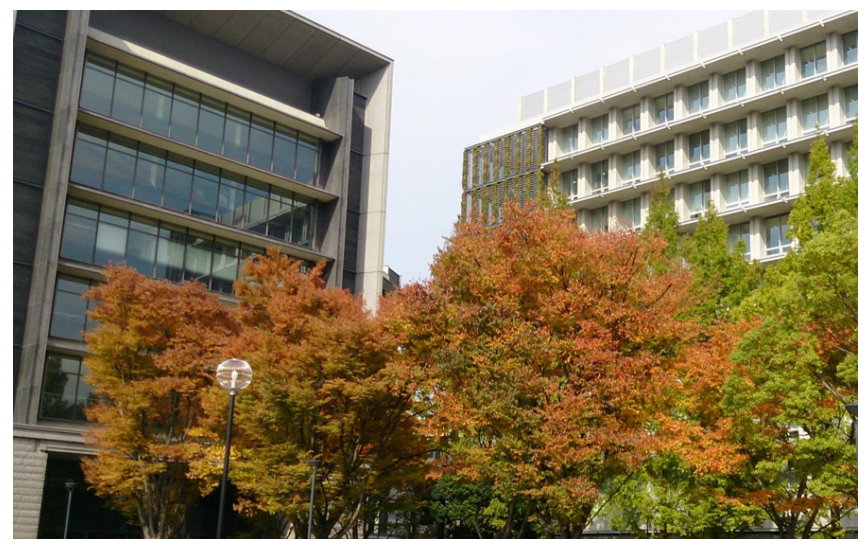

Fig. 1 創立 80 周年記念に建てられた中央図書館
らは, 2 年生で化学工学コースと分子工学コースに分かれる 新システムの導入を行い, 学生に専門科目を学ぶ意欲の醸成 を図っている。 なおこれらの内容は, 福岡大学のホームペー ジ (https://www.fukuoka-u.ac.jp/) ならびに化学システム工学 科のホームページ (http://www.tec.fukuoka-u.ac.jp/tk/index. html）を参考にした.

\section{2. 研究室の概要}

本研究室は 2011 年 4 月に筆者が田中隆一名誉教授の後任 として着任し, 発足した. 元々は有機合成を本分とする研究 室であったが, これを幾分方針転換し, 現在は高分子重合 $30 \%$ 程度，物性研究が 70\%程度の割合となっている。

着任直後もっとも意外であったことが, 大学院生の少なさ であった．私学の常として学部学生数は 100 名近くいるため, 各研究室には毎年 10〜13 名程度の卒論生が配属される。し かし筆者が着任したころは大学院に進学する学生は全学生中 2〜3 名程度に留まっていた。ささらに意外であったのは，あ まりそれを問題としていない当時の大学の風潮であった。個 人的にできることは限られているが，研究室を希望してきて くれた学生に大学院への進学を問いかけてみると, 学生の方 は大学院や研究というものをある程度意識していることが明

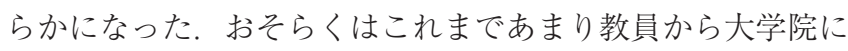
関する話題提供がなかったことが心理的な障壁となっていた のだと思われるが, これが払拭されると進学を真剣に考えて くれる学生が多くいることもわかった，幸いにして，着任 2 年目から 5 名, 8 名, 4 名, 6 名, 4 名, 5 名と続けて大学院に 進学してくれる学生に多数恵まれ, 研究を大いに進めること ができた。またこれは思いもよらぬことではあったが，2017 年には第 1 回の福岡大学大学院教育・研究指導功労賞を受賞 することができた。 その後学科の教員の陣容も変わり, 最近 では他の研究室でも大学院に進学する学生が増え, 化学シス テム工学科全体としてもおおよそ3割程度の大学院進学率に なっている. たた，近頃は他大学の大学院に進学する学生も 増え, より魅力ある研究テーマの設定など, さらなる工夫が 必要であろうと考えている。一方で博士課程進学者は, 昨今 の就職率の良さも手伝い, 伸び悩んでいる。これに関しては, 大学全体での抜本的な対策が必要であろうと考えている。

\footnotetext{
* = 814-0180 福岡市城南区七隈8-19-1
}

E-mail : shyao@fukuoka-u.ac.jp 


\section{3. 研究内容}

研究室を立ち上げるにあたり, 基盤となるテーマを高分子 の自己組織化とした。これは単に思い付きではなく, 自分が 企業という枠を外れたように高分子に「自由」というものを 与えてみたい，という気持ちからであった。 その中でも， 「結晶化」という, もっとも高分子が自己主張する, そのた めにこれまであまり取り扱われてこなかった現象に注目する ことにした。またそれらテーマを遂行するために自分が学生 に指導できることに限界があることは自明であったため, 学 会や展示会など, 外に出て, 身体を動かして, いろいろ体験 することで自学してもらうフィールドワークを重視したいと 考え, 研究室のモットーとしてホームページに揭げることと した ${ }^{1)}$.

現在もっとも人手をかけているテーマとしては，プラス チックの高度なマテリアルリサイクルプロセスの構築に関す る研究と側鎖結晶性ブロック共重合体による結晶性高分子の 表面改質・機能化に関する研究の二つが挙げられる. 以下に これらの研究を始めた経緯と現状について紹介する。

\section{3-1 プラスチックの高度なマテリアルリサイクルプロセス の構築}

福岡大学に着任する前に勤めていた三菱総合研究所では, 環境省からの委託業務としてリサイクルされたプラスチック の特性に関する調査を行っていた。 その折，工場内リサイク ル品では分子鎖切断を伴う化学劣化の痕跡がほとんどなく, 試験片物性もほぼ同じという妥当な結果を得ることができて いた。この調査案件自体はこれらの結果をまとめて報告書を 作成することで終了したが，それぞれの試験片の透明性や 触った硬さが大きく異なるなど, 報告書に記載できない感覚 的な差があることが気になっていた。

着任に際し, 調査時に用いて残っていた試料のペレットな らびに試験片を三菱総合研究所から譲り受け, 研究を開始し た。しかしながら当初は物性を評価できる装置が全くなく, できることは液体窒素中で破断し, その断面構造を見る程度 であった，そのような情況を知ってか知らずかは不明である が，2012 年に研究室に配属した冨永亜矢さん（2018 年に博 士号を取得）は，当初から精力的に本テーマに取り組んでく れた. 彼女の初めての研究成果である破断面観察結果を Fig. 2 に示す ${ }^{21}$. 三菱総合研究所での検討から試験片の力学 物性はほぼ同じであることが分かっていたが, それにもかか わらず図からわかるように内部構造が大きく異なっているこ とが明らかになった。 この結果を受け, 潤沢とは程遠い予算 をやりくりして熱プレス成形機と引張試験機を購入し, 本格 的な研究を開始した。 また三菱総合研究所での調査時に協力 企業であった広島リサイクルセンター・エコフィールの菅尾 氏と道上氏からも, 経費を無視した協力を得ることができ, 実際の容器包装リサイクルプラスチックの物性のペレタイズ 条件依存性などの, 実機を用いた研究を行うことができた。

これらの研究の結果, リサイクルされたプラスチックの物 性が低下している原因は, 従来常識とされてきた化学劣化に 伴う分子量の低下ではなく, 成形履歴などに伴い内部構造が 変化したための物理劣化であること, さらに成形法あるいは ペレタイズ法を工夫することで物性再生が可能であることを 明らかにすることができた，特にペレタイザーの先端に設置
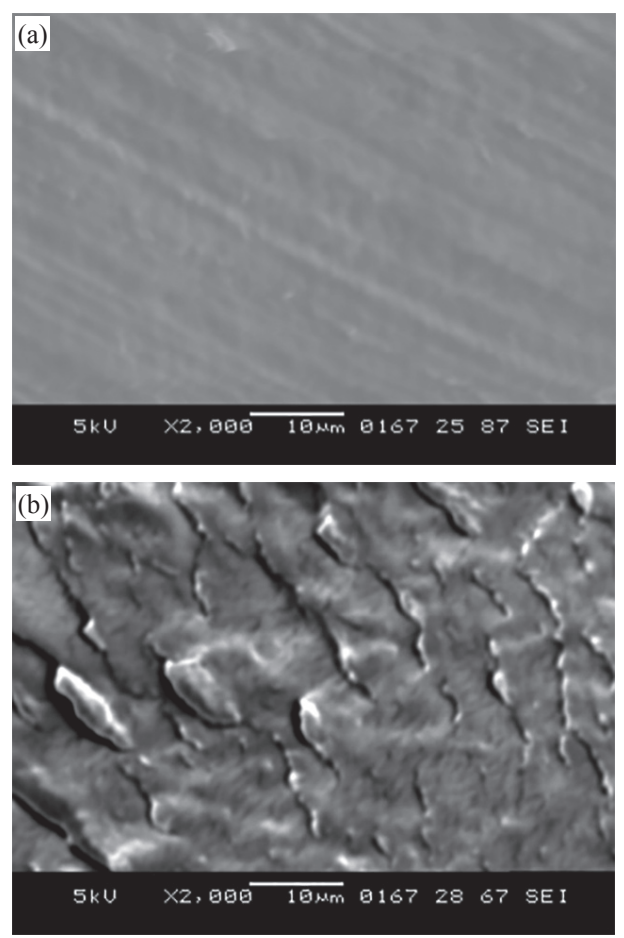

Fig. 2 バージン品および工場内リサイクル品の射出成形試験片の破断 面 SEM 写真

(a)：バージン品, (b)：工場内リサイクル品

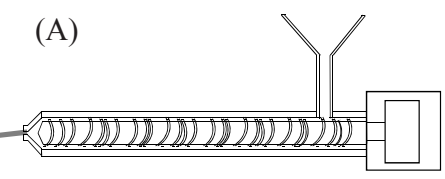

通常のペレタイザー

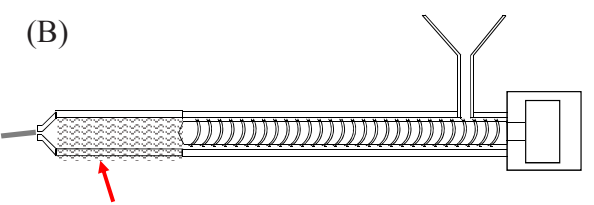

溶融樹脂溜まりを設けたペレタイザー

Fig. 3 通常のペレタイザーの (A) と, 今回考案した樹脂溜まりのある ペレタイザーの (B)の概念設計比較図

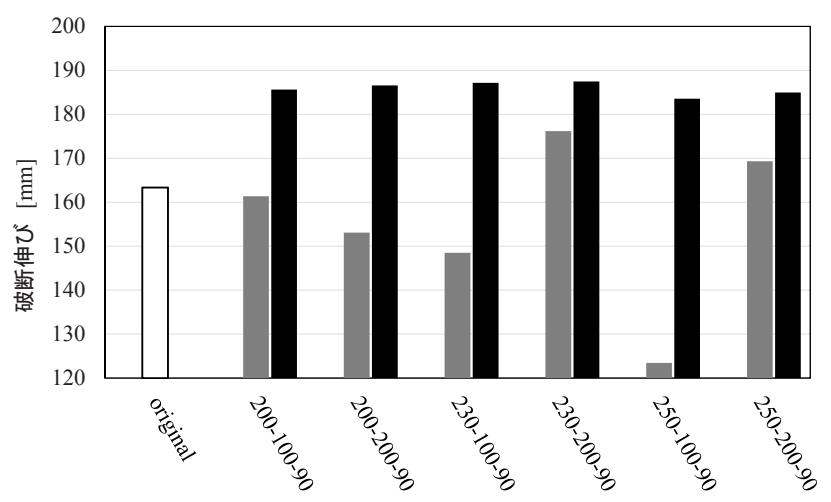

Fig. 4 種々のペレタイズ条件で作成したペレットでの破断伸びの樹脂 溜まり有無の依存性

白棒グラフ：オリジナルのペレットでの破断伸び

灰棒グラフ：樹脂溜まりの無い条件で作成したペレットでの值 黑棒グラフ：樹脂溜まりのある条件で作成したペレットでの值 横軸数字はペレタイズ条件 $\left(\right.$ 温度 $\left({ }^{\circ} \mathrm{C}\right)-$ スクリュー回転数 $(\mathrm{rpm})$-引取ギア回転数 $(\mathrm{rpm}))$ 
した新規装置要素である樹脂溜まりが物性向上に非常に効果 的であることを見出すことができた，樹脂溜まりの概念的設 計図を Fig. 3 に，また Fig. 4 にはポリプロピレン成分選別を 行った容器包装リサイクルプラスチックを用いてその効果を 評価した結果を示す。眓から明らかなように, 射出成形時に 再溶融されるにもかかわらず，樹脂溜まりを持つペレタイ ザーで作成したペレットを用いて射出成形した試験片が安定 して良好な物性を示すことがわかる゙

当初, この研究結果は当時の常識と大きくかけ離れていた ために，全く理解を得ることができなかった。それでも 2014 年に漸く環境省環境研究総合推進費に採択され, さら に2015 年の中間発表で高評価を得ることができ，2017年か らも引き続き採択を受けることができている。本研究テーマ は現在 Dr. Patchiya Phanthong さんが精力的取り組んでおり, 特に物理劣化に関する基礎研究では, せん断履歴が高分子の 力学特性を低下させ，成形法を最適化することで回復できる こと, またこれらの変化が内部構造と関連していることが明 らかになりつつある。ささらに種々の廃萧プラスチックに対す る実用的な高度再利用プロセスの検討に関する研究に関して も, 研究室を挙げて取り組んでいる.

\section{3-2 側鎖結晶性ブロック共重合体による難改質性プラス チックの表面改質}

本テーマもまた三菱総合研究所で行っていた業務中の, 中 小企業の技術コンサルティングから派生したテーマである. 当時コンサルを行っていた企業では, ポリエチレン微粒子分 散系を低粘度化できる高機能な分散剤の探索を行っていた。

良く知られているようにポリエチレンは非常に不活性な素材 であり難改質性であるとされている. ポリエチレン基板の場 合は一般的にプラズマなどの物理的手段で表面に官能基を導 入する手法で改質することが可能である. しかし粒子に対し てはこのような手法が適用できないため, 常識では分散荗は ないあるいは作ることはできない, とされていた。

本課題に対し，筆者は側鎖に長鎖アルカン鎖を持つモノ マーと親溶媒性モノマーから成る側鎖結晶性ブロック共重合 体が有意に機能するのではないかという見通しを立て, 高分 子設計を行った. Fig. 5 にそのときに設計した側鎖結晶性ブ ロック共重合体の化学構造を示す。この研究テーマの場合も, 当時コンサルを行っていた企業側空口であった市川賢氏が 非常に進取の気概に富んでおり，またリビングラジカル法に よるブロック共重合体の重合に長けていたことが幸いした。 彼はほぼ 2 週間で設計通りの側鎖結晶性ブロック共重合体を 重合し, これを高粘度のポリエチレン微粒子濃厚分散系へ添 加し，その粘度変化の評価実験を実施した。 その結果，驚く べきことに当該ブロック共重合体の $2 \mathrm{wt} \%$ 程度の希薄溶液を 10 滴ほど添加するだけで, 系の粘度が 2 桁以上も劇的に減 少する現象を見出した4)

この実験が行われた直後に筆者は福岡大学に移動したが, さらに幸運なことに市川氏との共同研究を継続することがで き, 基礎的な研究を積み重ねることができた。その結果, こ のブロック共重合体はポリプロピレンの微粒子に対しては全 く機能せず，また同じポリエチレンでも結晶性の違いにより 差があることなどがわかった。その後シミュレーションなど も参考にして，この現象はこれまで見出されてこなかった， 結晶同士の相互作用力により吸着特性が発現されるという,
結晶化超分子間力によるものであることが明らかになった. このメカニズムは Fig. 6 に示すようにイラスト化して説明で きる5

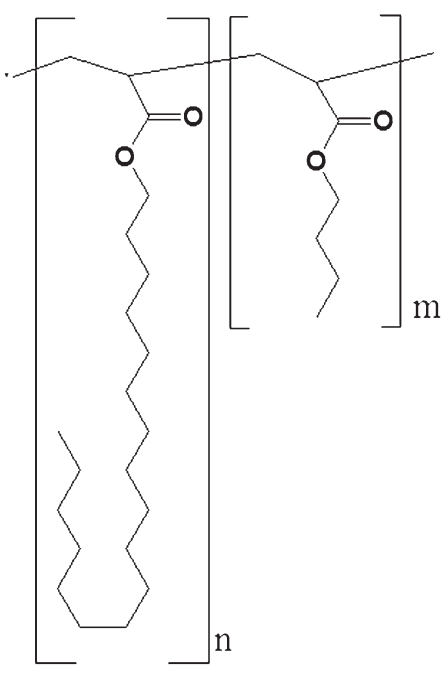

Fig. 5 材料設計を行った側鎖結晶性ブロック共重合体の化学構造

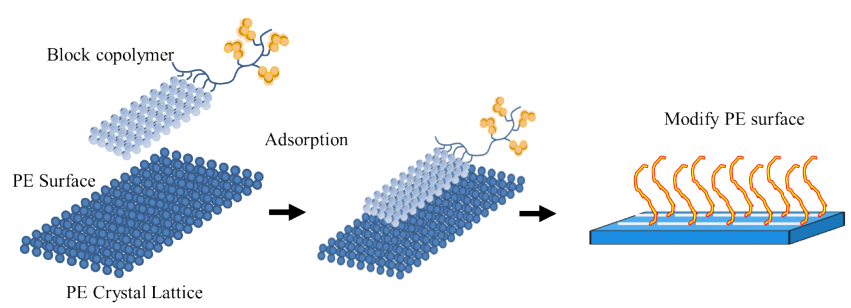

Fig. 6 側鎖結晶性ブロック共重合体が発現する結晶化超分子間力によ る表面改質メカニズム
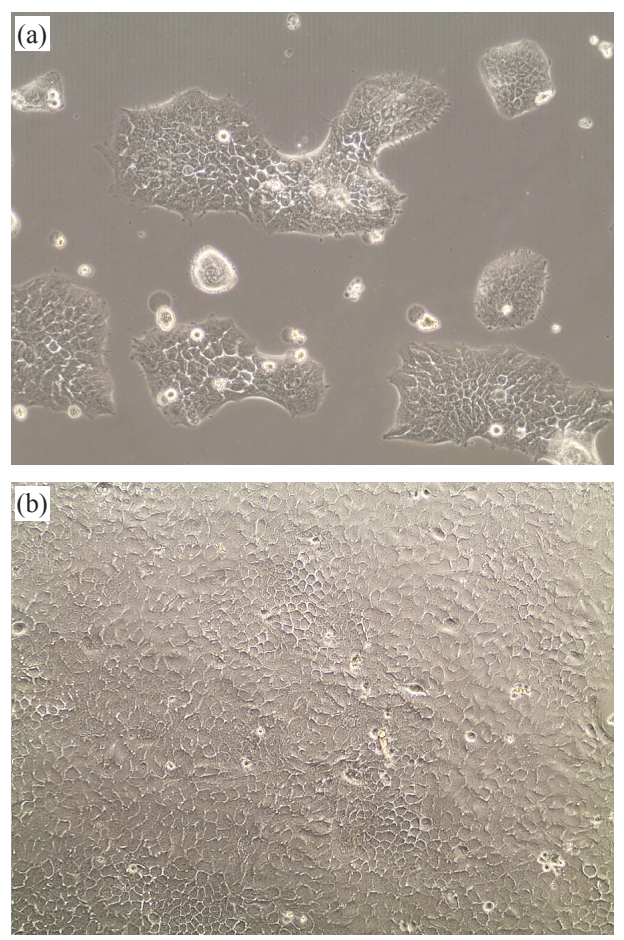

Fig. 7 市販の細胞培養血および改質した細胞培養血での細胞増殖の様子 (a)：市販の細胞培養血, (b)：改質した細胞培養血（福岡大学 薬学部 中島教授, 櫨川助教より提供) 


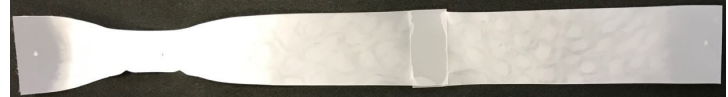

Fig. 8 側鎖結晶性ブロック共重合体により強固に接着性が付与された ポリエチレンフィルム

接合部では剥離せず，フィルム本体が延伸されている

本テーマはこれまで物理的な手法でしか改質できないと信 じ込まれていたポリエチレンが, 単にブロック共重合体の希 薄溶媒中に浸漬するだけで化学的に改質できるという点で画 期的である。また機能性を示すモノマー種を選択することに より，任意の物性をポリエチレン表面に付与することが可能 である。現在親水性や接着性だけでなく, 細胞培養特性 (Fig. 7 参照) の) なと， 幅広い用途への展開を計っている。ま た課題であった吸着力のコントロールも, 平井 翔博士の取 組みにより飛躍的に進歩しており, 現在では Fig. 8 に示すよ うに非常に強い接着特性を発揮できる段階にまで達してい る7)、またこのコンセプトを利用することで，他の難改質性 高分子への適用も試みている.

\section{4. おわりに}

述べてきたように，当研究室はこれまで脈々とした歴史が あるわけでもなく, 何をやらなくてはならない, という根本 的な使命があるわけでもない。したがって, 結構筆者の思い 付きのレベルで手を出しているところはあり, 反省点でもあ る。ただ，これまでの常識に縛られ，「リサイクルプラス チックの物性低下の主原因は化学劣化によるものであり, 再 生不可能である」とか, 「ポリエチレンは高結晶性でありか つ極性がないために化学的改質は不可能である」と最初から 決めつけることなく，いろいろな忠告に流されることなく， 種々挑戦してきたことは誇っても良いのではないかと考えて いる.

一方で,つき合わされるスタッフや学生・院生諸君には, 迷惑な話でもある。しかし筆者の与太話に惑わされることな く, 国内外の学会でのポスター賞の獲得や, 公的な機関や企 業との共同研究に結び付く実績を着実に積み上げてくれてい る。あまり表に出しては言っていないが, 感謝に堪えない.

以上，筆の進むままに書き進んできたが，最後に自分の ルーツを忘れていない証拠を Fig. 9 に示す。懐かしく思い出 される方もおられるであろうが, これは小野木重治先生が粘 弾性を説明するときに使用しておられた高分子溶液および実 験キットである。野木先生から松本孝芳先生に受け継がれ, 筆者が研究室を立ち上げたときに松本先生から託された. 作

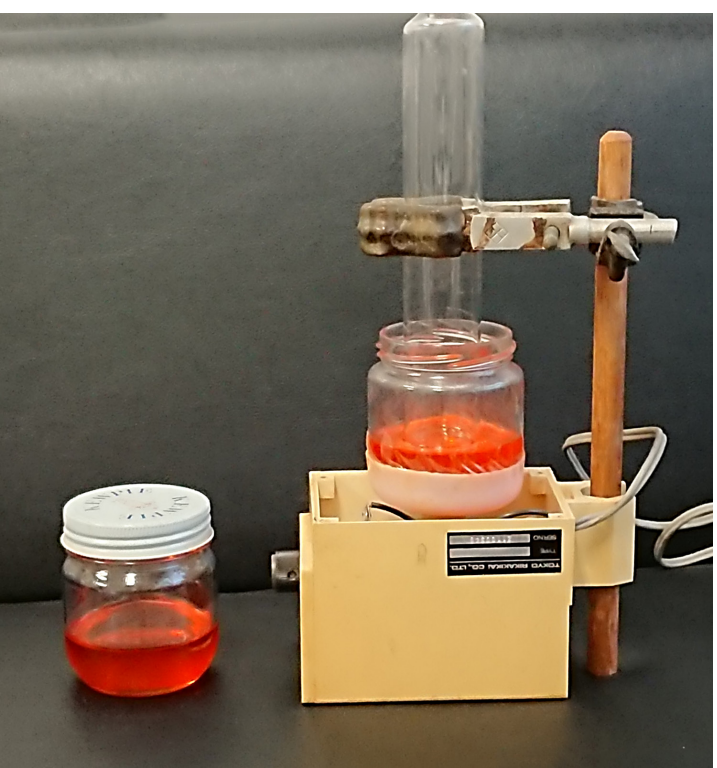

Fig. 9 小野木先生, 松本先生から引き継いだ粘弾性デモ用の試料一式

成されてからすでに半世紀は経っていると思うがいまだ現役 で，元気よく粘弾性的性質を示してくれており，学生の評判 も上々である。この粘り強さを見習い, 今後も研究に臨んで いきたいと考えている.

\section{REFERENCES}

1) Yao' laboratory HP https://www.cis.fukuoka-u.ac.jp/ shyao/ (Browsed 2019/1/20).

2) Yao S, Tominaga A, Fujikawa Y, Sekiguchi H, Takatori E, Nihon Reoroji Gakkaishi (J Soc Rheol Jpn), 41, 173 (2013).

3) Yao S, Tominaga A, Journal of the Japan Society of Material Cycles and Waste Management, 29, 116 (2018).

4) Yao S, Ichikawa S, Nihon Reoroji Gakkaishi (J Soc Rheol Jpn), 39, 181 (2011).

5) Miho Y, Hirai S, Nakano R, Sekiguchi H, Yao S, Polymer Journal, 50, 439 (2018).

6) Fukuoka University New Technology Presentation Meetings 2018 HP, https://shingi.jst.go.jp/kobetsu/fukuoka-u/2018 fukuoka-u/tech_property.html\#pbBlock73737 (Browsed 2019/1/20).

7) Hirai S, Obuchi H, Nakano R, Sekiguchi H, Yao S, SeikeiKakou, 30, 220 (2018). 